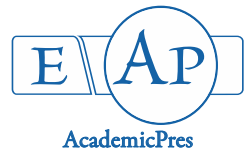

\title{
Changes in Nutrient Contents of Soil Across Different Land Uses in a Forest Reserve
}

\section{${ }^{1}$ Oludare Oladipo AGBOOLA ${ }^{1 *}$, Aderopo AKINSOJI ${ }^{1}$, Stephen OYEDEJI ${ }^{2}$}

\author{
${ }^{1}$ University of Lagos, UNILAG, Department of Botany, Nigeria; dareagboola@unilag.edu.ng ( ${ }^{*}$ corresponding author); drpknsj@gmail.com \\ ${ }^{2}$ University of Ilorin, UNILORIN, Department of Plant Biology, Nigeria; princeseyed1st@yahoo.com
}

\begin{abstract}
In order to assess the changes in soil chemical properties' resulting from conversion of forest to other agricultural land uses a study was conducted in Okomu Forest Reserve (Nigeria). Five soil samples collected from top and sub soils of marked points within the undisturbed forest, farmland, cocoa plantation, oil palm plantation and rubber plantation were analyzed for $\mathrm{pH}$, organic carbon, total nitrogen, available phosphorus, exchangeable acidity, sodium, potassium, calcium and magnesium. The results showed variations in all chemical parameters across the land use types with soil depths (top and sub soils). Soil pH ranged from 4.88 (in the cocoa plantation subsoil) to 6.75 (in the forest top soil). Soils (top and sub soils) of the rubber plantation, forest and cocoa plantation had the highest stock of soil organic carbon (SOC), $\mathrm{N}$ and exchangeable $\mathrm{Na}$ respectively. Available $\mathrm{P}$ was highest in the top soil of the rubber plantation and sub soil of the farmland. Exchangeable $\mathrm{Ca}$ and $\mathrm{Mg}$ were highest in the top soil of the forest and sub soil of the rubber plantation. Exchangeable $\mathrm{K}$ and $\mathrm{C}: \mathrm{N}$ was highest in the farmland top soil and cocoa plantation sub soil. Relationship among the chemical parameters varied with soil depth. Conversion of forest and cocoa plantation resulted in the highest decline $(55.78 \%$ and $44.40 \%)$ in soil $\mathrm{N}$. There is the need to regulate the conversion of natural forests to agricultural lands and plantations as conserve the nutrient cycling processes.
\end{abstract}

Keywords: conservation, farmland, land use, plantations, productivity, soil nutrients

\section{Introduction}

Land use changes have remarkable effects on the dynamics of soil properties (Ozgoz et al., 2013). A change from forest cover to cultivated land may hinder addition of litter that enhances nutrient content of soils (Ozgoz et al., 2013), increase rates of erosion (Biro et al., 2013), loss of soil organic matter and nutrient (Saha and Kukal, 2015), and accelerate rate of soil degradation (Barua and Haque, 2013). This process, in turn, leads to a decline in soil fertility and loss of biological activity and diversity (Yao et al., 2010). Vegetation cover is, therefore, a key indicator of soil degradation as plants play a role in the control of soil erosion (Cedar, 1998; Keesstra et al., 2009; Kropfl et al., 2013; Tejada and Benitez, 2014; Bochet, 2015).

Indeed, changes in land cover have significant effect on the amount and diversity of biomass returned to the soil, which also disrupt the richness of nutrient restored to the soil. It is perhaps a known fact that soil erosion intensity and amount of nutrient element loss varies depending on the vegetation type at a particular place and time. This is so because, the rate of nutrient element loss in both dissolved and sediment bound forms will depend on the ability of vegetation canopy to effectively intercept the direct impact of raindrops that strike the soil surface (Iwara, 2011). If the canopy is not dense enough or well developed, little nutrients return to the soil as well as large quantities of nutrient will be removed from the soil surface during periods of heavy rainstorm when the soil is saturated.

Different studies have examined the effects of land use/cover change on physico-chemical properties of the soil (Lal, 1996; Bossuyt et al., 1999; Eneji et al., 2003; Evrendileka et al., 2004; Emadi et al., 2008; Agoume and Birang, 2009; Gol, 2009; Offiong et al., 2009). These studies nevertheless characterized changes in soil properties in relation to emerging land use/cover change in their respective ecosystems. The conversion of Forest Reserve to other land-uses in recent times has caused many complex changes in the forest ecosystem whose impact raises diverse ecological problems (Henrik et al., 2010). Increasing population coupled with urban poverty has exacerbated the migration of people into rural areas especially villages closer or inside the Forest Reserves in Nigeria (Adeofun and Akinsanmi, 1997). This has led to the de-reservation of substantial parts of most of the Forest Reserves in Nigeria (such as Okomu, Omo, Oluwa, and Olokemeji forests) for the establishment of monoculture plantations, while encroachment by landless farmers for agricultural activities has further impoverished many (Ola-Adams, 1996, 
Ogunleye et al., 2004). The structural alteration of the potential forest reserves has not been without cost and has resulted in a mosaic of land-uses within the forest reserves. Both forest litters and soil microbes constitute an important resource that makes forests fertile for arable farming in the tropics (Akachukwu, 2006) and the fertility status of a soil is acknowledged to be a reflection of the soil properties and soil texture characteristics (Michel et al., 2010). The change in forest cover to other forms of land cover such as plantation and grassland results in the tremendous modification of canopy cover, thereby making the area affected susceptible to soil erosion; this affects the stock of soil organic carbon (SOC). The conversion of forest ecosystem to other forms of land cover may decrease the stock of SOC due to changes in soil moisture and temperature regimes, and succession of plant species with differences in quantity and quality of biomass returned to the soil (Offiong and Iwara, 2012).

The conversion of forest land to tree plantations and food crops plots has been shown to adversely affect soil carbon and nitrogen levels (Michel et al., 2010). There are also strong indications that the conversion of tropical forests into land for agriculture or plantation might have negative impacts on soil properties and the carbon budget (Hertel et al., 2009). Hence, a selection of appropriate ecological indicators with well-established sensitivity to disturbances will assist in assessing the extent of these impacts with a view to addressing the associated ecological problems.

Consequently, soil physical and chemical properties have been proposed as suitable indicators for assessing the effect of land-use changes and management (Janzen et al., 1992; Bremer et al., 1994; Alvarez and Alvarez, 2000). This approach has been used extensively by several authors to monitor land-cover and land-use change patterns (Schroth et al., 2002; Airiohuodion, 2003; Faboya, 2010; Michel et al., 2010). Similarly, a lot of studies have been carried out on the soil physiochemical and biological changes (Schroth et al., 2002; Tchienkoua and Zech, 2004; Walker and Desanker, 2004) over the humid tropical regions of the world. In spite of the economic importance of plantation forestry and agriculture, previous studies on the effects of different land-use types on soil properties in Nigeria are grossly inadequate, hence this study. The present study assesses variations in soil properties associated with different land-use types within Okomu Forest Reserve, Edo State, Nigeria.

\section{Materials and Methods}

Study area

Okomu Forest Reserve is located in Ovia South-West Local Government Area of Edo state and occupied an area of $1082 \mathrm{~km}^{2}$ within the lowland forest of Nigeria. It is lies geographically between longitudes $5^{\circ} \mathrm{N}$ to $5^{\circ} 30^{\prime} \mathrm{E}$ and latitudes $6^{\circ} \mathrm{N}$ to $6^{\circ} 10^{\prime} \mathrm{N}$ precisely between the River Osse and Siluko to the East and West respectively and about 40 $\mathrm{km}$ from Benin City, the state capital. The reserve derived its name from River Okomu from the Benin word 'Akomu' meaning unity. The reserve was named Okomu during the colonial constitution of the reserve.

Okomu area has well marked rainy and dry seasons. The dry season which lasts from November to March is usually accompanied by northeast trade wind that causes harmattan (Azeez et al., 2010). It receives a mean annual rainfall above $2500 \mathrm{~mm}$ per annum (Akinsorotan et al., 2011) falling mainly between March and October with the highest rainfall occurring in June, July and September. The mean monthly temperature is $30^{\circ} \mathrm{C}$. The relative humidity is high and usually not less than $65 \%$ during the afternoons in any month of the year.

\section{Collection of soil samples}

Five different land use types were identified within Okomu Forest Reserve to include oil palm plantation, cocoa plantation, rubber plantation, secondary forest and cultivated cropland/farmland and each is 0.5 ha in size. Five sampling points were marked out within each land use type and georeferenced using Garmin eTrex X GPS device (Table 1). Soil samples were collected from marked points from $0-15 \mathrm{~cm}$ (top soil) and $15-30 \mathrm{~cm}$ (sub soil) depths using a Stainless Dutch soil Auger. The soil samples were packed in labelled polythene bags, air dried in the laboratory and passed through $2 \mathrm{~mm}$ sieve prior to chemical analysis.

\section{Chemical analysis}

Soil $\mathrm{pH}$ was determined in $1.0 \mathrm{~N} \mathrm{KCl}$ employing a 1:1 soil/solution mixture (Thomas, 1996) and read with a digital $\mathrm{pH}$ meter after equilibration. Soil organic carbon was determined by the Walkley-Black wet oxidation method (Nelson and Sommers, 1996). Soil nitrogen was determined by the macro Kjeldahl method of digestion, distillation and back titration (Bremmer, 1996). Available phosphorus was determined by the Bray-P1 method (Kuo, 1996).

Table 1. Geo-position of soil sampling points within five land use types in Okomu Forest Reserve, Edo State, Nigeria

\begin{tabular}{|c|c|c|c|c|c|c|c|c|c|c|}
\hline $\begin{array}{c}\text { Sampling } \\
\text { points } \dagger\end{array}$ & \multicolumn{2}{|c|}{ Forest } & \multicolumn{2}{|c|}{ Farmland } & \multicolumn{2}{|c|}{ Cocoa plantation } & \multicolumn{2}{|c|}{ Oil palm plantation } & \multicolumn{2}{|c|}{ Rubber plantation } \\
\hline \multirow{2}{*}{1} & N06.41819 & \multirow{2}{*}{$178 \mathrm{ft}$} & N06.29560 & \multirow{2}{*}{$151 \mathrm{ft}$} & N06.29569 & \multirow{2}{*}{$149 \mathrm{ft}$} & N06.35301 & \multirow{2}{*}{$241 \mathrm{ft}$} & N06.39125 & \multirow{2}{*}{$305 \mathrm{ft}$} \\
\hline & E005.46671 & & E005.37022 & & E005.36821 & & E005.35764 & & E005.38937 & \\
\hline \multirow{2}{*}{2} & N06.41842 & \multirow{2}{*}{$189 \mathrm{ft}$} & N06.29567 & \multirow{2}{*}{$147 \mathrm{ft}$} & N06.29553 & \multirow{2}{*}{$142 \mathrm{ft}$} & N06.35305 & \multirow{2}{*}{$249 \mathrm{ft}$} & N06.39172 & \multirow{2}{*}{$298 \mathrm{ft}$} \\
\hline & E005.46689 & & E005.37030 & & E005.36813 & & E005.35787 & & E005.38954 & \\
\hline \multirow{2}{*}{3} & N06.41878 & \multirow{2}{*}{$191 \mathrm{ft}$} & N06.29560 & \multirow{2}{*}{$137 \mathrm{ft}$} & N06.29538 & \multirow{2}{*}{$138 \mathrm{ft}$} & N06.35314 & \multirow{2}{*}{$247 \mathrm{ft}$} & N06.39149 & \multirow{2}{*}{$304 \mathrm{ft}$} \\
\hline & E005.46704 & & E005.37053 & & E005.36803 & & E005.35797 & & E005.38927 & \\
\hline \multirow{2}{*}{4} & N06.41893 & \multirow{2}{*}{$182 \mathrm{ft}$} & N06.29539 & \multirow{2}{*}{$134 \mathrm{ft}$} & N06.29528 & \multirow{2}{*}{$134 \mathrm{ft}$} & N06.35346 & \multirow{2}{*}{$223 \mathrm{ft}$} & N06.39180 & \multirow{2}{*}{$308 \mathrm{ft}$} \\
\hline & E005.46716 & & E005.37064 & & E005.36827 & & E005.35805 & & E005.38912 & \\
\hline \multirow{2}{*}{5} & N06.41919 & \multirow{2}{*}{$185 \mathrm{ft}$} & N06.29520 & \multirow{2}{*}{$127 \mathrm{ft}$} & N06.29531 & \multirow{2}{*}{$134 \mathrm{ft}$} & N06.35320 & \multirow{2}{*}{$216 \mathrm{ft}$} & N06.39175 & \multirow{2}{*}{$310 \mathrm{ft}$} \\
\hline & E005.46824 & & E005.37088 & & E005.36853 & & E005.35828 & & E005.38872 & \\
\hline
\end{tabular}

†Distances indicated recorded in feet (ft) are height above sea level. 
416

Exchangeable acidity was determined by titration using 1.0 M KCl for extraction (Bertsch and Bloom, 1996). Soil exchangeable cations were extracted using $1.0 \mathrm{~N}$ ammonium acetate, $\mathrm{NH}_{4} \mathrm{OAc}$ buffered to $\mathrm{pH} 7.0$ (Thomas, 1982). The concentrations of $\mathrm{Ca}, \mathrm{Mg}, \mathrm{K}$ and $\mathrm{Na}$ in the filtrate were then determined by spectrophotometry. $\mathrm{Na}$ and $\mathrm{K}$ concentrations was determined using a flame photometer while $\mathrm{Ca}$ and $\mathrm{Mg}$ was determined using Atomic Absorption Spectrophotometer (AAS) (Buck Scientific 2.0).

\section{Data analysis}

Data on concentrations of soil $\mathrm{pH}$ and nutrients were analysed using GLM model in SAS 9.1.3 software for Windows (SAS Institute, 2003). The means were separated using Duncan's Multiple Range test at $\alpha=0.05$. Bar graphs for the concentrations of soil nutrients were plotted using Microsoft Excel 2013 (Microsoft Corporation, 2012). Bar graphs for deterioration indices were plotted using Origin 8 Pro for Windows (Origin Lab Corporation, 2007). Deterioration/improvement in soil nutrients in the land uses relative to the undisturbed forest was calculated using the deterioration index (DI) of Ekanade (1991) as adopted by Oyedeji et al. (2016) where:

$$
\text { Deterioration index, } D I,=\frac{X-X_{i}}{X} \times 100
$$

$X=$ mean value of soil nutrient in the forest soil (reference site); $X i=$ mean value of soil nutrient in the compared site. Note: a positive value indicates deterioration and a negative value indicates improvement.

\section{Results}

\section{Concentrations of soil chemical parameters}

There were significant differences $(\mathrm{P}<0.05)$ in soil $\mathrm{pH}$, organic carbon, nitrogen, phosphorus, exchangeable acidity and soil cations $(\mathrm{Na}, \mathrm{K}, \mathrm{Ca}$ and $\mathrm{Mg})$ in the different land uses. Significant variations also exist between the levels of the soil parameters in the top soil and sub soil. There were also significant interactions between the land use and soil depth (top and sub soils) for all assessed soil parameters (Table 2).
The soil $\mathrm{pH}$ ranged from very strongly acid (4.88) in the sub soil of cocoa plantation to neutral (6.75) in the top soil of Okomu forest. The top soil of cocoa plantation was most acidic (5.05) among the land uses. In all the land uses, $\mathrm{pH}$ was significantly higher in the top soil than the sub soil, except in the oil palm plantation (Fig. 1a). Organic carbon was generally highest in the rubber plantation $-1.46 \%$ and $1.25 \%$ respectively in the top soil and sub soil. The least \% OC in the top soil and sub soil were $0.80 \%$ and $0.73 \%$ in the cocoa plantation and farmland respectively. Soil OC was generally higher in the top soil than sub soil except in the cocoa plantation (Fig. 1b). Nitrogen content in the top soil and sub soil was significantly highest in the forest land $48.19 \mathrm{mg} \mathrm{kg}^{-1}$ and $47.72 \mathrm{mg} \mathrm{kg}^{-1}$ respectively. The least $\mathrm{N}$ content was in the top soil of the farmland $\left(21.31 \mathrm{mg} \mathrm{kg}^{-1}\right)$. The forest and cocoa plantation had higher $\mathrm{N}$ concentration in the top soil than the sub soil (Fig. 1c). Carbon-nitrogen ratio was significantly highest in the top soil of the farmland (555.59). The least C: $\mathrm{N}$ was in forest sub soil (212.47). The top soils of the land use types had higher C:N than the sub soils, except in the cocoa plantation (Fig. 1d). Available phosphorus concentration was generally highest in the top soil of the rubber plantation $\left(14.20 \mathrm{mg} \mathrm{kg}^{-1}\right)$ while the farmland had the highest $P$ in the sub soil $\left(10.12 \mathrm{mg} \mathrm{kg}^{-1}\right)$. The least levels of $P$ in the top soil and sub soil were $6.77 \mathrm{mg} \mathrm{kg}^{-1}$ and $5.63 \mathrm{mg} \mathrm{kg}^{-1}$ respectively in the oil palm plantation and forest (Fig. le). Exchangeable acidity was significantly highest in the top soil of cocoa plantation $(0.16 \mathrm{meq} / 100 \mathrm{~g})$. The sub soil of the forest had the lowest acidity $(0.05 \mathrm{meq} / 100 \mathrm{~g})$. Acidity was generally higher in the top soil than the sub soil, except in the oil palm plantation where measure of soil acidity was statistically the same $(0.10 \mathrm{meq} / 100 \mathrm{~g})$ in the top soil and sub soil (Fig. 1f).

Sodium had the highest concentrations among the exchangeable cations across the land use types. Exchangeable Na was highest in the top soil $\left(4.48 \mathrm{mg} \mathrm{kg}^{-1}\right)$ and sub soil $\left(5.01 \mathrm{mg} \mathrm{kg}^{-1}\right)$ of the cocoa plantation. The farmland and rubber plantation had the lowest concentrations in the top soil $\left(3.41 \mathrm{mg} \mathrm{kg}^{-1}\right)$ and sub soil $\left(3.09 \mathrm{mg} \mathrm{kg}^{-1}\right)$ respectively. $\mathrm{Na}$ was generally higher in the sub soil than top soil except in the rubber plantation. Exchangeable $\mathrm{K}$ was however highest in the top soil of the farmland $\left(0.87 \mathrm{mg} \mathrm{kg}^{-1}\right)$. The

Table 2. Results of analysis of variance and mean squares of soil chemical properties at two soil depths in five different land use types at two soil depths

\begin{tabular}{ccccccccccccc}
\hline Sources of variation & $\mathrm{df}$ & $\mathrm{pH}$ & $\% \mathrm{OC}$ & $\mathrm{N}$ & $\mathrm{C}: \mathrm{N}$ & $\mathrm{P}$ & $\begin{array}{c}\text { Ex. } \\
\text { acidity }\end{array}$ & $\mathrm{K}$ & $\mathrm{Na}$ & $\mathrm{Ca}$ & $\mathrm{Mg}$ \\
\hline Land use & 4 & $2.47^{*}$ & $0.28^{*}$ & $738.35^{*}$ & $49318.25^{*}$ & $25.88^{*}$ & $0.006^{*}$ & $0.08^{*}$ & $2.68^{*}$ & $4.15^{*}$ & $0.58^{*}$ \\
Soil depth & 1 & $1.56^{*}$ & $0.14^{*}$ & $192.43^{*}$ & $84191.35^{*}$ & $10.77^{*}$ & $0.011^{*}$ & $0.04^{*}$ & $1.47^{*}$ & $0.35^{*}$ & $0.02^{*}$ \\
Land use $\times$ soil depth & 4 & $1.26^{*}$ & $0.18^{*}$ & $111.72^{*}$ & $76299.59^{*}$ & $36.60^{*}$ & $0.001^{*}$ & $0.10^{*}$ & $1.07^{*}$ & $0.77^{*}$ & $0.12^{*}$ \\
Error & 40 & $8.04 \mathrm{E}-4$ & $3.94 \mathrm{E}-4$ & $6.10 \mathrm{E}-4$ & 51.53 & $2.94 \mathrm{E}-4$ & $1.92 \mathrm{E}-4$ & $1.28 \mathrm{E}-4$ & $1.47 \mathrm{E}-4$ & $4.25 \mathrm{E}-5$ & $4.79 \mathrm{E}-5$ \\
\hline
\end{tabular}

Table 3. Exchangeable cations ( $\mathrm{Na}, \mathrm{K}, \mathrm{Ca}$ and $\mathrm{Mg}$ in $\mathrm{mg} \mathrm{kg}^{-1}$ ) at top and sub soil in five different land use types

\begin{tabular}{|c|c|c|c|c|c|c|c|c|}
\hline \multirow{2}{*}{ Land use type } & \multicolumn{2}{|c|}{$\mathrm{Na}$} & \multicolumn{2}{|c|}{$\mathrm{K}$} & \multicolumn{2}{|c|}{$\mathrm{Ca}$} & \multicolumn{2}{|c|}{$\mathrm{Mg}$} \\
\hline & Top soil & Sub soil & Top soil & Sub soil & Top soil & Sub soil & Top soil & Sub soil \\
\hline Forest & $3.93^{c}$ & $4.04^{\mathrm{d}}$ & $0.65^{c}$ & $0.58^{e}$ & $2.90^{\mathrm{a}}$ & $1.90^{\mathrm{b}}$ & $1.17^{\mathrm{a}}$ & $0.76^{\mathrm{b}}$ \\
\hline Farmland & $3.41^{\mathrm{e}}$ & $4.61^{c}$ & $0.87^{a}$ & $0.71^{c}$ & $0.98^{\mathrm{e}}$ & $1.34^{\mathrm{e}}$ & $0.39^{\mathrm{e}}$ & $0.54^{\mathrm{e}}$ \\
\hline Cocoa plantation & $4.48^{\mathrm{a}}$ & $5.01^{\mathrm{a}}$ & $0.46^{\mathrm{e}}$ & $0.82^{\mathrm{a}}$ & $1.10^{\mathrm{d}}$ & $1.42^{\mathrm{d}}$ & $0.44^{\mathrm{d}}$ & $0.57^{\mathrm{d}}$ \\
\hline Oil palm plantation & $4.22^{b}$ & $4.67^{b}$ & $0.71^{\mathrm{b}}$ & $0.80^{\mathrm{b}}$ & $1.70^{c}$ & $1.49^{c}$ & $0.68^{c}$ & $0.60^{c}$ \\
\hline Rubber plantation & $3.68^{d}$ & $3.09^{e}$ & $0.55^{\mathrm{d}}$ & $0.61^{\mathrm{d}}$ & $2.71^{\mathrm{b}}$ & $2.39^{\mathrm{a}}$ & $0.95^{\mathrm{b}}$ & $0.95^{\mathrm{a}}$ \\
\hline
\end{tabular}

Means with different letter down the column are significantly different at $\mathrm{P}<0.05$ 
a)

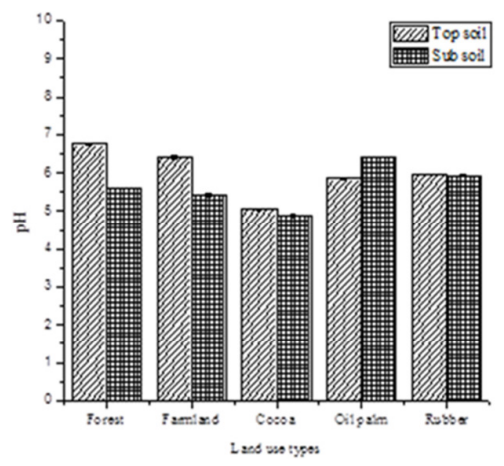

c)

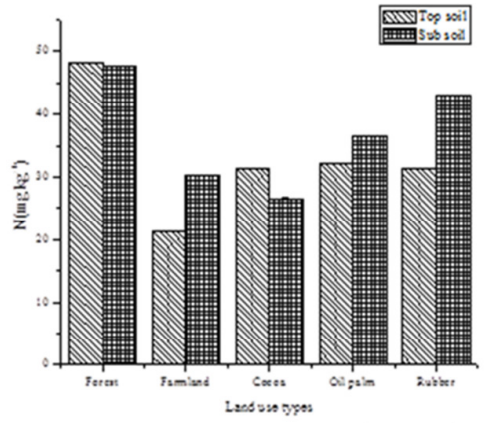

e)

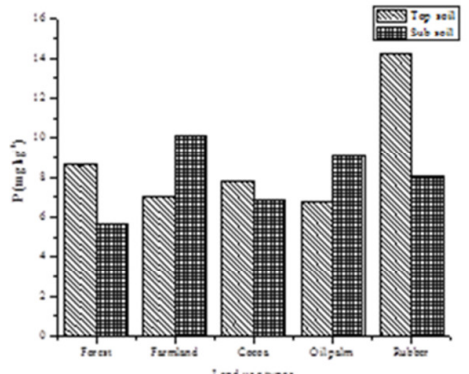

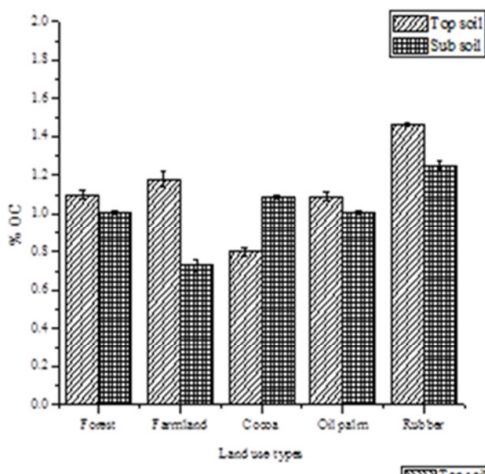

b)

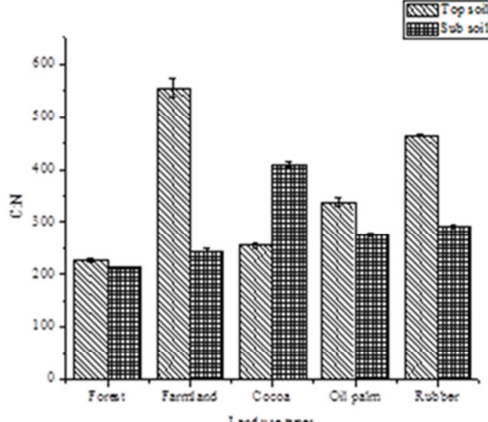

d)

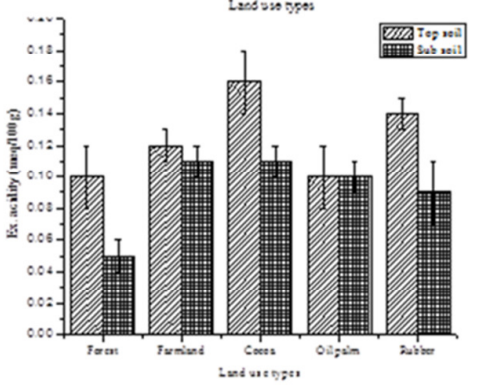

Fig. 1. (a) pH (b) organic carbon (c) N (d) C:N (e) P and (f) exchangeable acidity, in top and sub soil from five different land use types

cocoa plantation had the highest exchangeable $\mathrm{K}$ in the sub soil $\left(0.82 \mathrm{mg} \mathrm{kg}^{-1}\right)$ and least exchangeable $\mathrm{K}$ in the top soil $\left(0.46 \mathrm{mg} \mathrm{kg}^{-1}\right)$. Soil $\mathrm{K}$ in the top soil of the forest and farmland were higher than in the respective sub soils. Soil Ca was highest in the top soil of the forest $\left(2.90 \mathrm{mg} \mathrm{kg}^{-1}\right)$ and sub soil of the rubber plantation $\left(2.39 \mathrm{mg} \mathrm{kg}^{-1}\right)$. The farmland had the least $\mathrm{Ca}$ concentrations in the top soil $\left(0.98 \mathrm{mg} \mathrm{kg}^{-1}\right)$ and sub soil $\left(1.34 \mathrm{mg} \mathrm{kg}^{-1}\right)$. Soil Ca was higher in the top soil than the respective sub soils, except in the farmland. Soil $\mathrm{Mg}$ was highest in the top soil of the forest $\left(1.17 \mathrm{mg} \mathrm{kg}^{-1}\right)$ and sub soil of the rubber plantation $(0.95$ $\left.\mathrm{mg} \mathrm{kg}^{-1}\right)$. The farmland had the least concentration of $\mathrm{Mg}$ in the top soil $\left(0.39 \mathrm{mg} \mathrm{kg}^{-1}\right)$ and sub soil $\left(0.54 \mathrm{mg} \mathrm{kg}^{-1}\right)$. The concentration of $\mathrm{Mg}$ in the top soil and sub soil of the rubber plantation were at par $\left(0.95 \mathrm{mg} \mathrm{kg}^{-1}\right)$ (Table 3$)$.

Relationship between soil chemical parameters in the land use types

Pearson correlation index for the soil chemical parameters in the top soils (Table 4 ) showed a significant positive relationship between $\mathrm{pH}$ and $\mathrm{OC}(\mathrm{r}=0.51, \mathrm{p}<$ 0.01). Soil $\mathrm{pH}$ also correlated positively the soil exchangeable cations, except for $\mathrm{Na}$ where a significant negative relationship was observed $(\mathrm{r}=-0.71, \mathrm{p}<0.01)$. Soil $\mathrm{pH}$ also correlated negatively with exchangeable acidity $(\mathrm{r}=$ $-0.64, \mathrm{p}<0.01)$. Soil OC correlated positively with C:N (r $=0.65, \mathrm{p}<0.01)$, available $\mathrm{P}(\mathrm{r}=0.73, \mathrm{p}<0.01)$, exchangeable $\mathrm{Ca}(\mathrm{r}=0.49, \mathrm{p}<0.01)$ and $\mathrm{Mg}(\mathrm{r}=0.44, \mathrm{p}<$ $0.05)$. Soil OC also correlated negatively with exchangeable $\mathrm{Na}(\mathrm{r}=-0.75, \mathrm{p}<0.01)$. Soil $\mathrm{N}$ showed a positive correlation with $\mathrm{Ca}(\mathrm{r}=0.76, \mathrm{p}<0.01)$ and $\mathrm{Mg}(\mathrm{r}=0.84, \mathrm{p}$ $<0.01)$, and negatively correlated with C: $\mathrm{N}(\mathrm{r}=-0.79, \mathrm{p}<$ $0.01)$. C: $N$ relate positively with soil $\mathrm{K}(\mathrm{r}=0.59, \mathrm{p}<0.01)$ and negatively with $\mathrm{Na}(\mathrm{r}=-0.81, \mathrm{p}<0.01)$. Available $\mathrm{P}$ correlates positively with $\mathrm{Ca}(\mathrm{r}=0.65, \mathrm{p}<0.01)$ and $\mathrm{Mg}(\mathrm{r}$ $=0.53, \mathrm{p}<0.01)$ but negatively with $\mathrm{K}(\mathrm{r}=-0.44, \mathrm{p}<0.05)$. Exchangeable acidity relates negatively with $\mathrm{K}(\mathrm{r}=-0.48, \mathrm{p}$ $<0.05)$ and $\mathrm{Mg}(\mathrm{r}=-0.44, \mathrm{p}<0.05)$. $\mathrm{Na}$ and $\mathrm{K}$ are negatively correlated $(\mathrm{r}=-0.67, \mathrm{p}<0.01)$, while $\mathrm{Ca}$ and $\mathrm{Mg}$ are positively correlated $(\mathrm{r}=0.99, \mathrm{p}<0.01)$.

In the sub soil, soil $\mathrm{pH}$ correlated positively with $\mathrm{N}(\mathrm{r}=$ $0.52, \mathrm{p}<0.01)$ and negatively with $\mathrm{C}: \mathrm{N}(\mathrm{r}=-0.51, \mathrm{p}<$ $0.01)$. Soil OC correlated positively with $\mathrm{C}: \mathrm{N}(\mathrm{r}=0.40, \mathrm{p}<$ $0.05), \mathrm{Ca}$ and $\mathrm{Mg}(\mathrm{r}=0.75, \mathrm{p}<0.01$ respectively) and negatively with $\mathrm{Na}(\mathrm{r}=-0.58, \mathrm{p}<0.01)$ and available $\mathrm{P}(\mathrm{r}=$ $-0.51, \mathrm{p}<0.01)$. Soil $\mathrm{N}$ correlated positively with $\mathrm{Ca}(\mathrm{r}=$ 
418

Table 4. Pearson correlation for soil chemical properties in the top soil of five land use types

\begin{tabular}{|c|c|c|c|c|c|c|c|c|c|c|}
\hline & $\mathrm{pH}$ & OC & $\mathrm{N}$ & C:N & $\mathrm{P}$ & Ex. acidity & $\mathrm{Na}$ & K & $\mathrm{Ca}$ & $\mathrm{Mg}$ \\
\hline $\mathrm{pH}$ & 1.00 & & & & & & & & & \\
\hline $\mathrm{OC}$ & $0.51^{\prime \prime}$ & 1.00 & & & & & & & & \\
\hline $\mathrm{N}$ & 0.33 & -0.12 & 1.00 & & & & & & & \\
\hline C:N & 0.23 & $.649^{\prime \prime}$ & $-0.79^{\prime \prime}$ & 1.00 & & & & & & \\
\hline $\mathrm{P}$ & 0.03 & $0.73^{\prime \prime}$ & 0.11 & 0.23 & 1.00 & & & & & \\
\hline Ex. Acidity & -0.64 & -0.18 & -0.39 & 0.10 & 0.23 & 1.00 & & & & \\
\hline $\mathrm{Na}$ & $-0.71^{\prime \prime}$ & $-0.75^{*}$ & 0.33 & $-0.81^{\prime \prime}$ & -0.30 & 0.21 & 1.00 & & & \\
\hline K & $0.66^{\prime \prime}$ & 0.28 & -0.35 & 0.59 & $-0.44^{\circ}$ & $-0.48^{\circ}$ & $-0.67^{\prime \prime}$ & 1.00 & & \\
\hline $\mathrm{Ca}$ & $0.49^{\circ}$ & $0.54^{\prime \prime}$ & 0.76 & -0.28 & $0.65^{\prime \prime}$ & -0.37 & -0.14 & -0.25 & 1.00 & \\
\hline $\mathrm{Mg}$ & 0.54 & $0.44^{\circ}$ & 0.84 & -0.37 & $0.53^{\prime \prime}$ & $-0.44^{\circ}$ & -0.09 & -0.20 & $0.99^{\circ \prime}$ & 1.00 \\
\hline
\end{tabular}

Values are correlation coefficient ${ }^{*}$ significant at 0.05 level and ${ }^{* *}$ significant at 0.01 level.

Table 5. Pearson correlation for soil chemical properties in the subsoil of five land use types

\begin{tabular}{|c|c|c|c|c|c|c|c|c|c|c|}
\hline & $\mathrm{pH}$ & $\mathrm{OC}$ & $\mathrm{N}$ & C:N & $\mathrm{P}$ & $\begin{array}{c}\text { Ex. } \\
\text { acidity }\end{array}$ & $\mathrm{Na}$ & $\mathrm{K}$ & $\mathrm{Ca}$ & $\mathrm{Mg}$ \\
\hline $\mathrm{pH}$ & 1.00 & & & & & & & & & \\
\hline $\mathrm{OC}$ & 0.16 & 1.00 & & & & & & & & \\
\hline $\mathrm{N}$ & $0.52^{*}$ & 0.39 & 1.00 & & & & & & & \\
\hline C:N & $-0.51 "$ & $0.40^{\circ}$ & -0.66 & 1.00 & & & & & & \\
\hline $\mathrm{P}$ & 0.33 & $-0.51^{*}$ & -0.46 & -0.13 & 1.00 & & & & & \\
\hline Ex. acidity & -0.24 & -0.20 & -0.81 & $0.55^{\circ}$ & 0.64 & 1.00 & & & & \\
\hline $\mathrm{Na}$ & -0.37 & -0.58 & $-0.75^{*}$ & 0.36 & 0.17 & 0.38 & 1.00 & & & \\
\hline $\mathrm{K}$ & -0.15 & -0.22 & $-0.85^{*}$ & $0.65^{\circ}$ & 0.38 & 0.66 & $0.81^{\circ}$ & 1.00 & & \\
\hline $\mathrm{Ca}$ & 0.32 & $0.75^{\prime \prime}$ & $0.77^{*}$ & -0.21 & -0.37 & $-0.45^{\circ}$ & $-0.97^{*}$ & -0.76 & 1.00 & \\
\hline $\mathrm{Mg}$ & 0.32 & $0.75^{*}$ & $0.76^{*}$ & -0.21 & -0.36 & -0.44 & $-0.97^{* *}$ & -0.76 & 1.00 & 1.00 \\
\hline
\end{tabular}

Values are correlation coefficient ${ }^{*}$ significant at 0.05 level and ${ }^{* *}$ significant at 0.01 level

$0.77, \mathrm{p}<0.01)$ and $\mathrm{Mg}(\mathrm{r}=0.76, \mathrm{p}<0.01)$ and negatively with C:N $(\mathrm{r}=-0.66, \mathrm{p}<0.01)$, available $\mathrm{P}(\mathrm{r}=-0.46, \mathrm{p}<$ $0.05)$, exchangeable acidity $(\mathrm{r}=-0.81, \mathrm{p}<0.01), \mathrm{Na}(\mathrm{r}=-$ $0.75, \mathrm{p}<0.01)$ and $\mathrm{K}(\mathrm{r}=-0.85, \mathrm{p}<0.01)$. C:N correlated positively with exchangeable acidity $(\mathrm{r}=0.55, \mathrm{p}<0.01)$ and $\mathrm{K}(\mathrm{r}=0.65, \mathrm{p}<0.01)$. Available $\mathrm{P}$ also correlated positively with exchangeable acidity $(r=0.64, p<0.01)$. Soil $\mathrm{Na}$ and exchangeable acidity both shared a positive correlation with $\mathrm{K}$ and negative correlations with $\mathrm{Ca}$ and $\mathrm{Mg}$. Soil $\mathrm{K}$ correlated negatively with $\mathrm{Ca}$ and $\mathrm{Mg}(\mathrm{r}=-0.76, \mathrm{p}<0.01$ respectively). Ca perfectly and positively correlated with $\mathrm{Mg}$ in the sub soil $(\mathrm{r}=1.00, \mathrm{p}<0.01)$ (Table 5).

Deterioration index for soil chemical nutrients in the land use types

The deterioration index (DI) for nutrient elements in Figs. 2a-b expresses the relative percentage of the chemical parameters in the land uses to that in the forest soil. A positive DI denotes a deterioration of the measured parameter while a negative DI denotes improvement of the parameter over that in the forest soil.

The result of deterioration index revealed positive DI for OC in the top soil of cocoa and oil palm plantations with $27.27 \%$ and $0.91 \%$ respectively. There was negative DI (improvement) for OC in the farmland $(-7.27 \%)$ and rubber plantation $(-30.00 \%)$. There was deterioration (positive DI) in nitrogen in the four land uses with the farmland accounting for the highest (55.78\%) in the top soil. Available P deteriorated in the farmland, cocoa and oil palm plantations with $18.66 \%, 9.85 \%$ and $21.55 \%$ respectively. There was marked improvement (negative DI) in available $\mathrm{P}$ in the rubber plantation (-64.54\%). Exchangeable $\mathrm{Na}$ improved in the top soil of the cocoa ($13.99 \%)$ and oil palm plantations $(-7.38 \%)$, while $\mathrm{K}$ improved in the farmland (-33.85\%) and oil plantation ($9.23 \%$ ). Exchangeable $\mathrm{Ca}$ and $\mathrm{Mg}$ showed different levels of deterioration in the different land uses (Fig. 2a).

In the sub soil, there was improvement in OC except in the farmland where a positive deterioration was observed (27.0\%). Soil N deteriorated in the four land use types with the cocoa plantation having the highest (44.40\%). Available $\mathrm{P}$ improved (negative DI) in the sub soil of the land use types. Exchangeable $\mathrm{Na}$ also improved in the sub soils except in the rubber plantation where deterioration was observed (23.50\%). There was improvement in sub soil exchangeable $\mathrm{K}$ across the land use types. Exchangeable $\mathrm{Ca}$ and $\mathrm{Mg}$ deteriorated in land use types except the rubber plantation (Fig. 2b).

\section{Discussion}

Soil $\mathrm{pH}$ in the acidic range in the cocoa plantation is in line with earlier report by Ololade et al. (2010) for cocoa plantation in Ile-Oluji, Ondo State. $\mathrm{pH}$ of the top soil in this study tend to increase with exchangeable $\mathrm{K}, \mathrm{Ca}, \mathrm{Mg}$ and organic carbon. Cations are known to increase soil $\mathrm{pH}$ through alkalization thereby creating a favourable condition for microbes to act on plant litter (Opala et al., 2012). Juo and Manu (1996) found that $\mathrm{pH}$ tend to decrease with decrease in soil nutrient stocks. This phenomenon may be related to cation uptake by plant, with subsequent release of $\mathrm{H}^{+}$ions, organic matter decomposition into organic acids, 


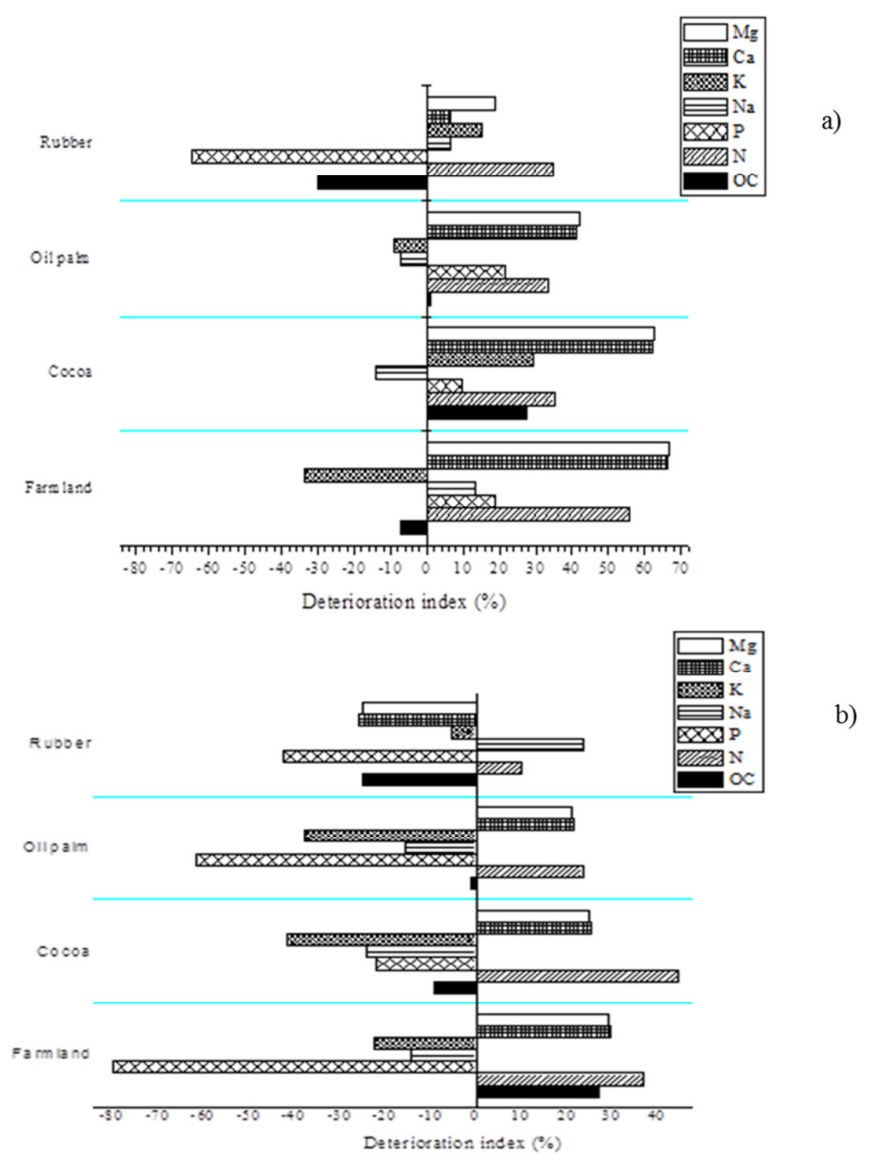

Fig. 2. Deterioration index for soil minerals from (a) top soil and (b) sub soil in four land use types in relation to a forest land

increased $\mathrm{CO}_{2}$ level through root respiration and nitrification. Conversion of natural forest into monoculture plantations of cocoa and oil palm resulted in a decline $(27.3 \%$ and $0.9 \%)$ in soil organic carbon (SOC). Michel et al. (2010) reported significant reduction in SOC in plantations and mixed crop fields compared to natural forest in Cote D'Ivoire, and attributed this to lack of under storey vegetation associated with agricultural lands. High $\mathrm{C}: \mathrm{N}$ alone, as in the farmland, does not suggest good health of the soil, as low $\mathrm{N}, \mathrm{pH}$ and $\mathrm{CEC}$ in the site will negatively influence the growth of plants. Lewandowski (2002) concluded that high C:N (low soil $\mathrm{N}$ ) dictates slow decomposition of accumulated biomass and may trigger nitrogen deficiency in plants. Deciduous nature of some trees species in established monoculture plantations (such as cocoa and rubber) build-up of biomass (Abou Rajab et al., 2016) that support the slightest spark of fire, thus accounting significantly in volatilization loss of labile nutrients such as nitrogen (Certini, 2005). Management of such monoculture plantations often eliminate other species including native legumes that contribute significantly to soil nitrogen stock. Although leguminous plants constitute a significant part of conventional cropping system, leaching and volatilization loss limit the availability of the nutrient (Oyedeji et al., 2016). Kutiel and Naveh (1987) in their study of pine forest soil reported 25\% decrease in $\mathrm{N}$ following burning. The National Wildlife Coordinating
Group (2001) also reported that volatilization loss significantly affected $\mathrm{N}$, and to a lesser extent $\mathrm{P}$. The slow mobility of $\mathrm{P}$ in soils may be responsible for its low susceptibility to loss by volatilization.

Improvement in soil $\mathrm{Ca}$ in the rubber plantation compared to the undisturbed forest in this study supported by the findings of Singh (1998) who reported higher soil Ca in Tectona grandis plantation. Improvement in $\mathrm{Na}$ and $\mathrm{K}$ in the sub soils across the land uses supports the notion of McGrath et al. (2001) that soil cation exchange capacity (CEC) increased following conversion of forest to pasture or field crops. According to Blake et al. (1999), such improvement often varies with soil chemistry, texture and depth. Such variations possibly accounted for the inconsistencies in the concentrations of the cations across the land uses and with soil depth. In general, decrease in the $\mathrm{CEC}$ is reflected in lower $\mathrm{pH}$ and organic matter contents in the soils (Owusu-Bennoah, 1997). The resultant low concentrations of $\mathrm{Ca}$ and $\mathrm{Mg}$ in the top soil and sub soil of the farmland despite high concentration of both cations in the forest soil underscore the need to conserve the forest. Watters (1971) observed that when forest was cleared for cultivation, there was a slight decrease in the cations exchange capacity at all soil depth.

Assessing the impact of land uses on soil organic carbon alone is grossly inadequate since soil organic matter is not chiefly carbon but contains hydrogen, oxygen, nitrogen, 
420

phosphorus, sodium, potassium, calcium, magnesium and other micronutrient elements (Gebreyesus, 2013; USDA, 2014). Although soil organic matter can be partitioned conveniently into these fractions, the components and amount of the end product is not static but reflect a dynamic equilibrium influenced by soil properties and by the quantity of annual inputs of plant and animal residues to the ecosystem (Bot and Benites, 2005). There is the need to protect forest cover and regulate conversion of forests to other land uses as to conserve the soil and ensure efficient nutrient cycling. Agro-ecological practices such as no till farming (conservation agriculture), cover cropping, green manuring and intercropping nitrogen-fixing legumes that improve soil organic matter and nitrogen will go a long way to improve productivity in forest converted to agricultural lands and plantations.

\section{References}

Abou Rajab Y, Leuschner C, Barus H, Tjoa A, Hertel D (2016). Cacao Cultivation under Diverse Shade Tree Cover Allows High Carbon Storage and Sequestration without Yield Losses. PLOS ONE 11(2): e0149949.

Adeofun CO, Akinsanmi FA (1997). Assessment of deforestation in a lowland area of South West Nigeria using remote sensing techniques. Nigerian Journal of Forestry 27:30-31.

Agoume V, Birang AM (2009). Impact of landuse systems on some physical and chemical soil properties of an Oxisol in the humid forest zone of Southern Cameroon. Tropicultura 27:15-20.

Airiohuodion OO (2003). An assessment of soil-plant dynamics in OmoOsun forest reserve of southwestern Nigeria, Unpublished MSc Thesis, Institute of Ecology and Environmental Studies, Obafemi Awolowo University, Ile-Ife.

Akachukwu AE (2006). Disappearing forests, the consequences and the challenges of sustainable development in Nigeria. In: Proceedings of the 31st Annual conference of the Forestry Association of Nigeria Popoola L(Eds), 20th-25th Nov 2006.

Akinsorotan OA, Ogunjemite BG, Afolayan T (2011). Assessment of the large mammals of Arakhuan range, Okomu National Park, Nigeria. Ethiopian Journal of Environmental Studies and Management 4:25-37.

Alvarez R, Alvarez CR (2000). Soil organic matter pools and their association with carbon mineralization kinetics. Soil Science Society of America Journal 64(1):184189.

Azeez IO, Ikponmwonba OS, Popoola L, Amusa TO (2010). Land use activities among forest environments' dwellers in Edo State, Nigeria: Implications for livelihood and sustainable forest management. International Journal of Social Forestry3(2):164-187.

Barua SK, Haque NS (2013). Soil characteristics and carbon sequestration potentials of vegetation in the degraded hills of Chittagong, Bangladesh. Land Degradation \&Development 24:63-71.

Bertsch PM, Bloom PR (1996). Aluminum. In: Methods of soil analysis. Sparks DL(Ed). Madison, Soil Science Society of America pp 517-550..

Blake L, Goulding KWT, Mott CJB, Johnston AE (1999). Change in soil chemistry accompanying acidification over more than 100 years under woodland and grass at Rothamsted Experimental Station, UK. European Journal of Soil Science 50:401-412.

Bochet $\mathrm{E}$ (2015). The fate of seeds in the soil: a review of the influence of overland flow on seed removal and its consequences for the vegetation of arid and semiarid patchyecosystems. Soil 1:131-146.

Bossuyt B, Deil J, Deckers J (1999). Changes Following cultivation and reforestation of loess soils in central Belgium: consequences for future land use. The Land 3:151-166.

Bot A, Benites J (2005). Importance of soil organic matter: key to droughtresistant soil and sustainable food production. In: FAO Soil Bulletin 80, Food and Agricultural Organization of the United Nation, Rome, pp. $1-78$.

BremerE, Janzen HH,Johnson AM (1994). Sensitivity of total light fraction and mineralizable organic matter to management practices in a Lethbridge. Canadian Journal of Soil Science 74:131-138.

Bremner JM (1996). Nitrogen total. In: Sparks DL (Ed). Methods of soil analysis, part 3, chemical methods. Soil Science Society of America: Madison, Wisconsin pp 1085-1121.

Cerdà A (1998). The influence of aspect and vegetation on seasonal changes in erosion under rainfall simulation on a clay soil in Spain. Canadian Journal of Soil Science 78:321-330.

Certini G (2005). Effect of fire on properties of soil - A review. Oecologia 143:1-10.

Ekanade O (1991). The nature of soil properties under mature forest and plantations of fruiting and exotic trees in the tropical rainforest fringes of Southwestern Nigeria. Journal of World Forest Resource Management 5:101-114.

Emadi M, Emadi M, Baghermejah HF, Saffari M (2008). Effects of land use changes on selected soil physical and chemical properties in North Highlands of Iran. Journal of Applied Sciences 8(3):496-502.

Eneji AE, Agboola AA, Aiyelari EA, Honna T, Yamamoto S, Irshad M, Endo T (2003). Soil Physical and Micronutrient Changes following Clearing ofa Tropical Rainforest.J For Res 8(3):217-221.

Evrendileka F, Celik I, Kilic S (2004). Changes in soil organic carbon and physical soil properties along adjacent Mediterranean forest, grassland and cropland ecosystems in Turkey. Journal of Arid Environments 59:743-752.

Faboya IO (2010). Assessment of soil nutrient status under different tree species combinations plantation in Ogbese forest reserve in Ekiti State. Unpublished MSc Thesis, Institute of Ecology and Environmental Studies, Obafemi Awolowo University, Ile-Ife.

Gebrelibanos Tsehaye, Mohammed Assen (2013). Effects of land-use/cover changes on soil properties in a dryland watershed of Hirmi and its adjacent agro ecosystem: Northern Ethiopia. International Journal of Geosciences Research 1(1):45-57.

Gol M (2009). Effects of land use change on soil properties and organic carbon at Dagdami River Catchments in Turkey. Journal of Environmental Biology 301:825-830.

Henrik H, Gaetan D, Brigitte B, Christian M (2010). Negative or positive effects of plantation and intensive forestry on biodiversity: A matter of scale and perspective. The Forestry Chronicle 86(3):354-364

Hertel D, Harteveid MA, Leuschner C (2009). Conversion of a tropical forest into agroforest alters the fine root-related carbon flux to soil. Soil Biology and Biochemistry 41:481-490.

Iwara AI, Ewa EE, Ogundele FO, Adeyemi JA, Otu CA (2011). Ameliorating effects of palm oil mill effluent on the physical and chemical properties of soil in Ugep, Cross River State, South-southern Nigeria. International Journal of Applied Science and Technology (5):106-112. 
Janzen HH, Campbell CA, Brant SA, Lanfond, GP, Townley S (1992). Light-fraction organic matter in soils from long-term crop rotations. Soil Science Society of America Journal 8:200-213.

Juo ASR, Manu A (1996). Nutrient effect on modification of shifting cultivation in West Africa. Journal of Agriculture, Ecosystem and Environment. 58:49-60.

Keesstra SD, van Dam O, Verstraeten G, van Huissteden J (2009). Changing sediment generation due to natural reforestation in the Dragonja catchment, SW Slovenia. Catena 78:60-71.

Kröpfl AI, Cecchi GA, Villasuso NM, Distel RA (2013). Degradation and recovery processes in Semi-Arid patchy rangelands of northern Patagonia, Argentina. Land Degradation \& Development 24:393-399.

Kuo S (1996). Phosphorus. In: Bridgham JM(Ed). Methods of soil analysis, Part 3. ASA andSSSA, Madison, WI pp 869-919.

Kutiel P, Naveh Z (1987). The effect of fire on nutrients in a pine forest soil. PlantSoil 104:269-274.

Lal R (2007). Constraints to adopting no-till farming in developing countries. Soil and Tillage Research 94:1-3.

Lewandowski A (2002). Organic matter management. University of Minnesota Extension, The University of Minnesota. Retrieved 27 May 2017 from http://www.extension.umn.edu/agriculture/tillage/soilmanagement/soil-management-series/organic-matter-management/.

McGrath SP, Zhao FJ, Lombi E (2001). Plant and rhizosphere process involved in phytoremediation of metal-contaminated soils. Plant and Soil232:207-214.

Michel KY, Pascal KTA, Souleymane K, JeromeET, Yao T, Luc A, Danielle $B$ (2010). Effects of land-use types on soil organic carbon and nitrogen dynamics in mid-west Cote d'Ivoire. European Journal of Scientific Research 2:211-222.

Nelson DW, Sommers LE (1982). Total carbon, organic carbon and organic matter. Methods of soil analysis. Part 2. Chemical and microbiological properties. In: Page AL, Miller RH, Keeney DR(Eds). 2nd ed. Madison WI pp 539-579.

Offiong RA, Iwara AI (2012) Quantifying the stock of soil organic carbon using multiple regression model in a fallow vegetation, Southern Nigeria. Ethiopian Journal of Environmental Studies and Management 5(2):166-172.

Offiong RA, Atu JE, Njar GN, Iwara AI (2009). Effects of land use change on soil physicochemical properties in a South-Southern Nigeria. African Journal of environment, Pollution and Health 7:47-51.

Ogunleye AJ, Adeola AO, Ojo LO, Aduradola AM (2004). Impact of farming activities on vegetation in Olokemeji Forest reserve, Nigeria Global Nest 6(2):131-140.

Ola-Adams BA (1996). Conservation and Management of biodiversity. In: Ola-Adams BA, Ojo LO (Eds). Biospheres reserves for Biodiversity Conservation and Sustainable Development, Anglophone Africa. Proceedings of the Inception Meeting and Training Workshop. January 1996.

Ololade IA, Ajayi IR, Gbadamosi AE, Mohammed OZ, Sunday AG (2010). Study on effects of soil physico-chemical properties on cocoa Production in Ondo State. Modern Applied Science 4(5):273-278.
Opala PA, Okalebo JR, Othieno CO (2012). Effects of organic and inorganic materials on soil acidity and phosphorus availability in a soil incubation study. ISRN Agronomy doi:10.5402/2012/597216.

OriginLab Coorporation (2007). OriginPro 8SR0 v8.0724. One Roundtable Plaza, Northhampton, MA01060.

Owusu-Bennoah E, Szilas E, Hansen HEB, Borggaard OK (1997). Phosphate sorption in relation to aluminium and iron oxides of Oxisols from Ghana Commun. Communications in Soil Science \& Plant Analysis 28:685-697.

Oyedeji S, Onuche FJ, Animasaun DA, Ogunkunle CO, Agboola OO, Isichei $A O$ (2016). Short-term effects of early-season fire on herbaceous composition, dry matter production and soil fertility in guinea savanna, Nigeria. Archives of Biological Sciences 68(1):7-16.

Ozgoz E, Gunal H, Acir N, Gokmen F, Birol M, Budak M (2013). Soil quality and spatial variability assessment of land use effects in a tipic haplustoll. Land Degradation \& Development 24:277-286.

Saha D, Kukal ZP (2015). Soil structural stability and water retention characteristics under different land uses of degraded 5 lower Himalayas of North-West India. Land Degradation \& Development 26:263-271.

SAS Institute (2003). SAS 9.1.3 Service Pack 4. SAS Institute Inc., Cary, NC 27513, USA.

Schroth G, Sammya ADA, Teixeira WG, Haag D, Liebereei R (2002). Conversion of secondary forest into agroforestry and monoculture plantation in Amazion: consequences for biomass, litter and soil carbon stocks after 7 years. Forest Ecology and Management 163:131-150.

Singh SP (1998). Chronic disturbance, a principal cause of environmental degradation in developing countries. Environmental Conservation 25:1-2.

Tchienkoua M, Zech W (2004). Organic carbon and plant nutrient dynamics under three land uses in the highland of West Cameroon. J Agriculture,Ecosystems \& Environment 104:673-679.

Tejada M, Benítez C (2014). Effects of crushed maize straw residues on soil biological properties and soil restoration. Land Degradation \& Development 25:501-509.

Thomas GW (1982). Exchangeable cations. In: Page AL et al. (Eds). Methods of Soil analysis, part 2. Chemical and microbiological properties. 2nd ed. Agron. Monogr.9, ASA andSSSA, Madison WI.

Thomas GW (1996). Soil pH and soil acidity. In Sparks DL(Ed). Methods of soil analysis: Chemical methods, part 3. Soil Sci Soc of Am, Madison WI.

Tchienkoua M, Zech W (2004). Organic carbon and plant nutrient dynamics under three land uses in the highland of West Cameroon. Agriculture, Ecosystems \& Environment 104:673-679.

Watters RF (1971) ShiftingCultivation in Latin America. Rome: FAO.

Yao MK, Angui PKK, KonateS, Tondoh JE, Tano Y, Abbadie L, Benest D (2010). Effects of land use types on soils organic carbon and nitrogen dynamics in Mid-West Cote d'voire. European Journal of Scientific D manch in.)11 on 